\title{
An Interesting Case of "Pituitary Macroadenoma" That Resolved with Levothyroxine Therapy
}

\author{
Srinivasa P. Munigoti ${ }^{1}$ Satish Satyanarayana ${ }^{1}$ Santhosh Krishnamurthy ${ }^{1}$ \\ ${ }^{1}$ Fortis Hospital, B. G. Road, Bengaluru, India \\ Address for correspondence Dr. Srinivasa P. Munigoti, MD, MRCP, \\ 154/9, Bannerghatta Road, Opposite IIM-B, Bengaluru, Karnataka \\ Indian J Neurosurg 2016;5:37-39. \\ 560076, India (e-mail: spmunigoti@gmail.com).
}
Abstract
Keywords
- primary hypothyroidism
- neurosurgery
- pituitary macroadenoma

This is a rare case of asymptomatic severe primary hypothyroidism presenting for the first time as a pituitary macroadenoma to the neurosurgical team, which resolved after treatment with levothyroxine $\left(T_{4}\right)$ without the need for surgery.

\section{Case}

A 14-year-aged girl presented to the neurosurgical team in January 2013 with mild headache and neck pain radiating to the left shoulder. After initial bedside assessment that was normal, she underwent magnetic resonance imaging (MRI) on January 5, 2013, which revealed a normal spine but incidentally showed a macroadenoma arising from the pituitary gland abutting the optic chiasm (-Fig. 1).

Given the closeness to the optic chiasm, surgery via transsphenoidal route was planned pending endocrine evaluation.

\section{Endocrine Assessment}

The patient attained menarche aged 12 years, and her menstrual cycles have been regular since. Her growth and milestones have been normal as was her academic and sport performance at school till she came to medical attention. She had no significant past medical problems that needed regular medication.

On examination, she was of normal built and had no characteristic features pointing toward any endocrine disorder. Systemic examination was also completely normal. She measured $40 \mathrm{~kg}$ in weight and was $146 \mathrm{~cm}$ tall. Her blood pressure (sitting right arm) in the clinic was $110 / 70 \mathrm{~mm} \mathrm{Hg}$. Bedside visual confrontation test was normal.

\section{Investigations}

Follicle-stimulating hormone (FSH): $6.18 \mu \mathrm{IU} / \mathrm{L}, \mathrm{LH}$ : $2.26 \mu \mathrm{IU} / \mathrm{L}$, prolactin: $76 \mathrm{ng} / \mathrm{mL}$.

8 AM cortisol: $27 \mu \mathrm{g} / \mathrm{dL}$.

Early morning growth hormone (GH): $2.34 \mathrm{ng} / \mathrm{mL}$, insulin-like growth factor 1 (IGF 1): $109 \mathrm{ng} / \mathrm{mL}$.

Fasting blood sugar: $77 \mathrm{mg} / \mathrm{dL}$.

Total triiodothyronine $\left(\mathrm{T}_{3}\right):<40 \mathrm{ng} / \mathrm{dL}$, total thyroxine $\left(\mathrm{T}_{4}\right):<1.00 \mu \mathrm{g} / \mathrm{dL}$, and thyroid-stimulating hormone (TSH): $1000 \mu \mathrm{IU} / \mathrm{mL}$ with very strongly positive TPO antibody titer.

Visual perimetry showed no field defect.

\section{Follow-up}

In view of profound primary hypothyroidism, neurosurgery was deferred and she was initiated on levothyroxine (L-thyroxine) therapy. Biochemical test results are summarized as follows ( $\mathbf{- T a b l e ~} \mathbf{1}$ ).

Patient has remained clinically and biochemically euthyroid, and is completely symptom free since.

Repeat MRI of the brain (30/09/2014) after the treatment

(C) 2016 Neurological Surgeons' Society

License terms of India

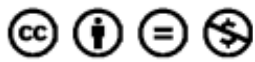

received

November 5, 2015

accepted

November 18, 2015

published online

February 24, 2016
DOI http://dx.doi.org/

10.1055/s-0036-1572380. ISSN 2277-954X. 


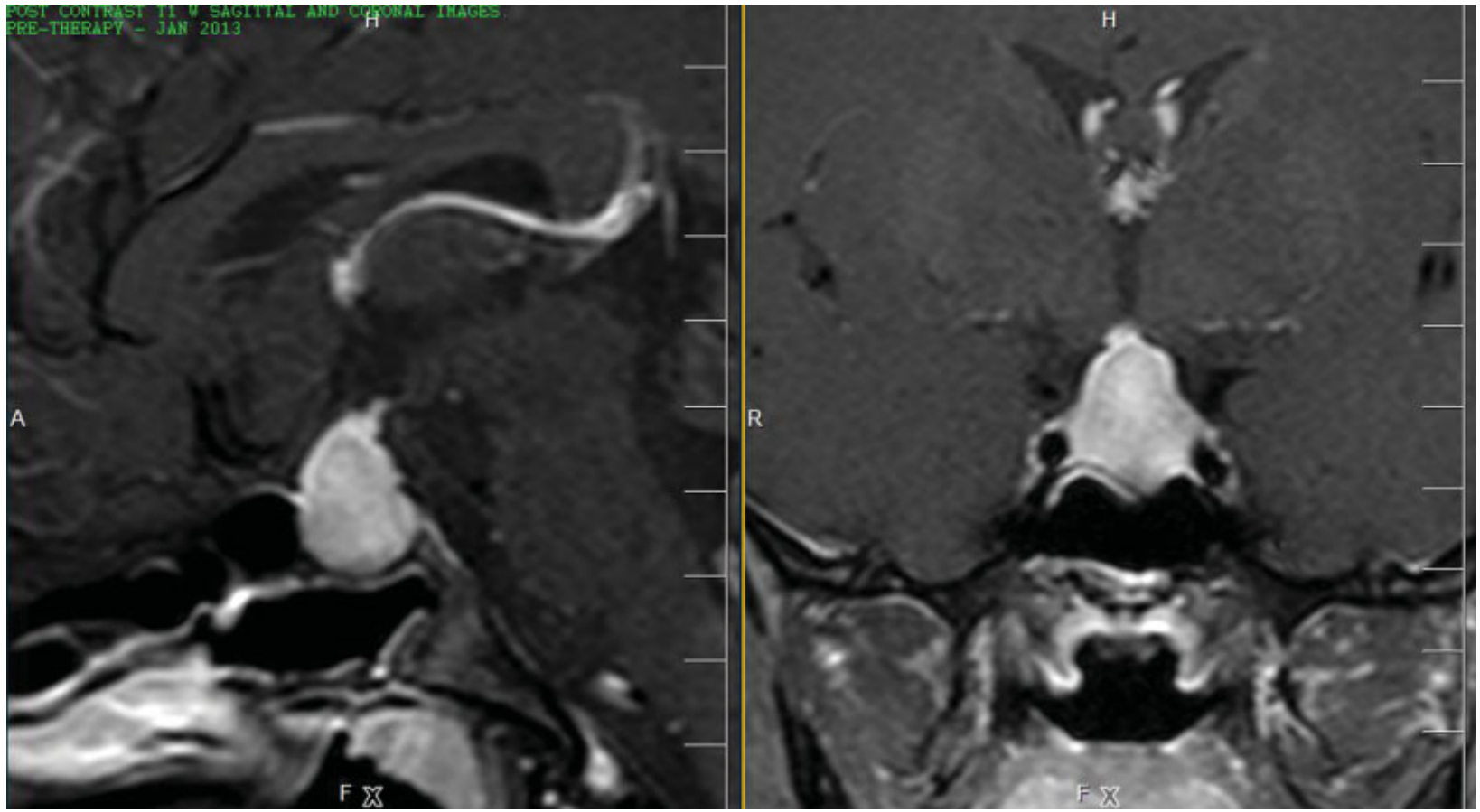

Fig. 1 MRI of the brain: T2W image shows mildly hyperintense lesion involving the anterior pituitary which turns hypointense on T1W image. It measures $1.9 \mathrm{~cm}$ superoinferiorly, $1.4 \mathrm{~cm}$ anteroposteriorly, and $1.7 \mathrm{~cm}$ transversely. Suprasellar component is seen to mildly impinge on the optic chiasm. No evidence of extension to cavernous sinus was noticed.

Table 1 Follow-up results of thyroid function tests after initiation of levothyroxine

\begin{tabular}{|l|l|l|l|}
\hline Investigations & January 6, 2013 & February 10, 2013 & March 13, 2014 \\
\hline Total $\mathrm{T}_{3}$ & Undetectable & $0.85 \mathrm{ng} / \mathrm{dL}(0.8-2)$ & $1.59 \mathrm{ng} / \mathrm{dL}(0.8-2)$ \\
\hline Total $\mathrm{T}_{4}$ & Undetectable & $5.74 \mu \mathrm{g} / \mathrm{mL} / \mathrm{dL}(4-12)$ & $9.65 \mu \mathrm{g} / \mathrm{dL}(4-12)$ \\
\hline $\mathrm{TSH}$ & $>100 \mu \mathrm{IU} / \mathrm{mL}(0.5-4.3)$ & $>100 \mu \mathrm{lU} / \mathrm{mL}$ & $3.77 \mu \mathrm{lU} / \mathrm{mL}$ \\
\hline Prolactin & $76 \mathrm{ng} / \mathrm{mL}$ & $25.49 \mathrm{ng} / \mathrm{mL}(<25)$ & 14.50 \\
\hline
\end{tabular}

Abbreviations: $\mathrm{T}_{3}$, triiodothyronine; $\mathrm{T}_{4}$, thyroxine; $\mathrm{TSH}$, thyroid-stimulating hormone.

with L-thyroxine showed significant reduction in the size of adenoma (-Fig. 2).

\section{Discussion}

Thyrotroph hyperplasia is a well-recognized entity in presence of primary hypothyroidism, and cases from literature suggest that the incidence of pituitary enlargement in primary hypothyroidism can range from 25 to $81 \%,{ }^{1}$ and the incidence is proportionately high with higher values of TSH. ${ }^{2}$ Primary hypothyroidism causing low circulating thyroxine levels is thought to result in the loss of negative control on hypothalamo-pituitary-thyroid axis, resulting in the increase in thyrotroph-releasing hormone (TRH) from hypothalamus. This in turn has a stimulatory effect on thyrotrophic cells in the pituitary leading to increased TSH levels and hyperplasia of those cells in the pituitary gland sometimes simulating an adenoma. ${ }^{3,4}$ TRH is also known to exert a weak stimulatory effect on lactotroph cells, resulting in mild to moderate hyperprolactinemia. ${ }^{4}$

Recognition of this entity is crucial especially in children/ adolescents as in present case as near-complete regression can be achieved with thyroxine replacement therapy, thus avoiding neurosurgery and its consequences including potential hypogonadotrophic hypogonadism and subsequent difficulties with childbearing. ${ }^{5-7}$ This case also clearly illustrates the importance of thorough preoperative hormonal assessment of pituitary masses, including thyroid function tests. ${ }^{8}$ 


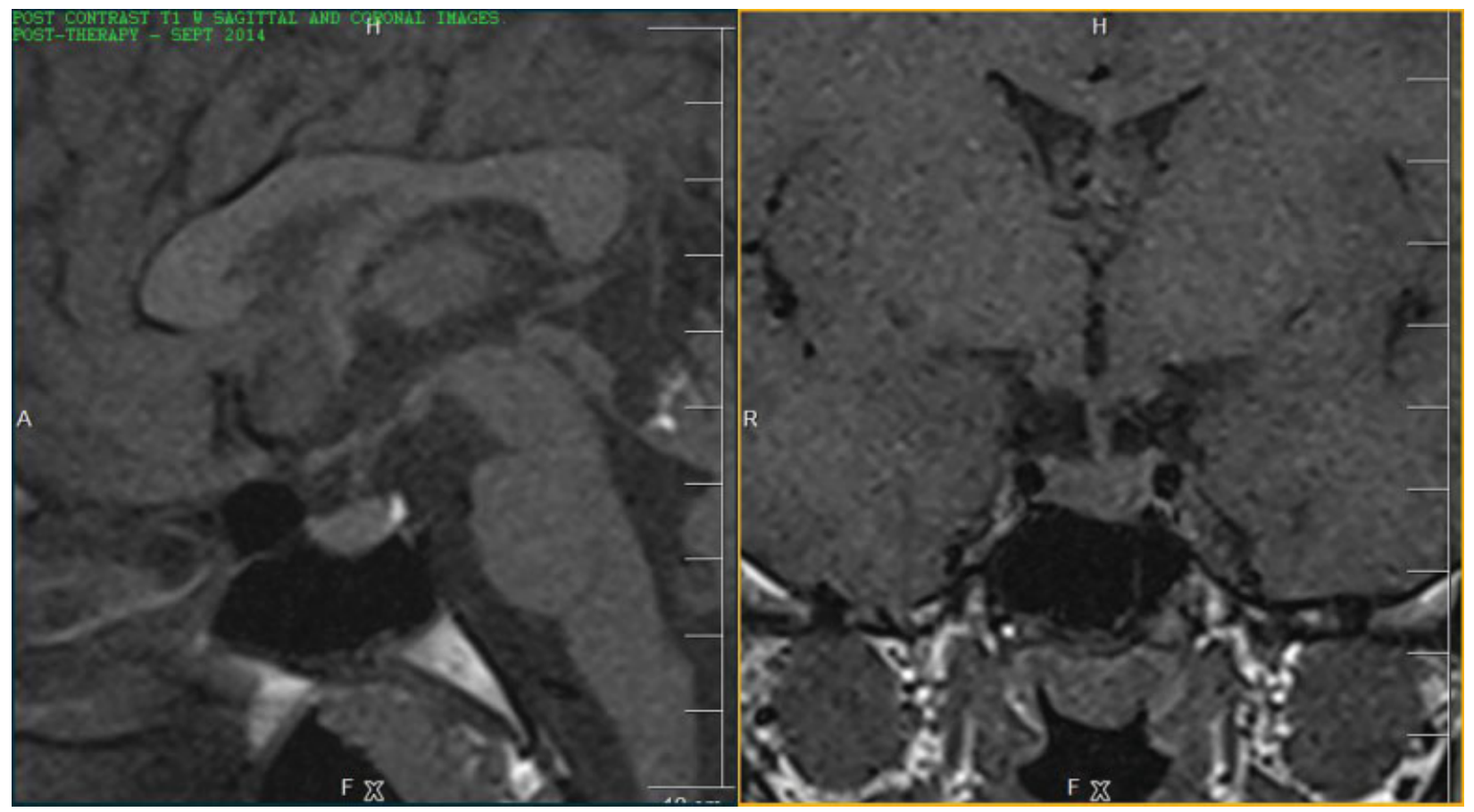

Fig. 2 MRI of the brain done showed T2W image shows mildly hyperintense lesion involving the anterior pituitary, which turns hypointense on T1W image. It measures $0.67 \mathrm{~cm}$ superoinferiorly, $0.9 \mathrm{~cm}$ anteroposteriorly, and $0.9 \mathrm{~cm}$ transversely.

\section{References}

1 Beck-Peccoz P, Brucker-Davis F, Persani L, Smallridge RC, Weintraub BD. Thyrotropin-secreting pituitary tumors. Endocr Rev 1996;17(6):610-638

2 Khawaja NM, Taher BM, Barham ME, et al. Pituitary enlargement in patients with primary hypothyroidism. Endocr Pract 2006; 12(1):29-34

3 Joshi AS, Woolf PD. Pituitary hyperplasia secondary to primary hypothyroidism: a case report and review of the literature. Pituitary 2005;8(2):99-103

4 Yen PM. Physiological and molecular basis of thyroid hormone action. Physiol Rev 2001;81(3):1097-1142
5 Nicholas WC, Russell WF. Primary hypothyroidism presenting as a pituitary mass. J Miss State Med Assoc 2000;41(3): 511-514

6 Young M, Kattner K, Gupta K. Pituitary hyperplasia resulting from primary hypothyroidism mimicking macroadenomas. $\mathrm{Br} \mathrm{J}$ Neurosurg 1999;13(2):138-142

7 Ehirim PU, Kerr DS, Cohen AR. Primary hypothyroidism mimicking a pituitary macroadenoma. Pediatr Neurosurg 1998; 28(4):195-197

8 Betônico CC, Rodrigues R, Mendonça SC, Jorge PT. [Primary hypothyroidism mimicking pituitary macroadenoma]. Arq Bras Endocrinol Metabol 2004;48(3):423-426 